\title{
Sobre o método ontológico-genético em Filosofia
}

\author{
Nicolas Tertulian*
}

\section{Resumo}

O ponto de partida do autor é a constatação de que a posição de Lukács no cenário filosófico contemporâneo está longe de ser elucidada. Um pesado silêncio envolve desde há muito tempo suas duas obras de síntese: A Estética e A ontologia do ser social. Em contrapartida, trata-se agora de mostrar que Lukács foi o primeiro a empreender uma genealogia das múltiplas atividades da consciência e de suas objetivaçóes (a economia, o direito, a política e suas instituiçóes, a arte ou a filosofia) a partir da tensão dialética entre subjetividade e objetividade. Ou seja, no pensamento final do filósofo húngaro há um método "ontológico-genético", visto que ele se dedica a mostrar a estratificação progressiva das atividades do sujeito (por exemplo, atividade utilitária, atividade hedonista e atividade estética), indicando as transiçóes e as mediaçôes, até circunscrever a especificidade de cada uma em função do papel que desempenha na fenomenologia da vida social.

Palavras-chave: Ontologia. G. Lukács. Método.

* Professor da Escola de Altos Estudos em Ciências Sociais (Paris). Tradução do francês de Glória Goulart da Silva Campos (UFSC - GEPOC). Revisão Técnica: Ester Vaisman (UFMG) e Mario Duayer (UFF). 
A posição de Lukács na paisagem filosófica contemporânea está longe de ser elucidada. Um pesado silêncio envolve durante décadas suas duas obras de síntese: A Estética e $A$ ontologia do ser social. O filósofo criou um método original do pensamento, que traz soluçôes inéditas e fecundas para muitos dos grandes problemas da reflexão filosófica: por exemplo, a relação entre a intencionalidade da consciência e a rede de cadeias causais objetivas ou também da relação entre "historicidade" e "transcendência" das grandes categorias do espírito (arte, ciência, religião, filosofia).

$\mathrm{O}$ caráter ontológico singulariza seu pensamento em meio às teorias contemporâneas da vida social. Sem dúvida, pensadores como Nicolai Hartmann ou Roman Ingarden precederam Lukács no destaque concedido à intentio recta (orientação à realidade em sua autonomia ontológica) em comparação com a intentio obliqua (atenção dirigida à reflexividade da consciência), mas Lukács foi o primeiro a estabelecer uma genealogia das múltiplas atividades da consciência e de suas objetivaçóes (a economia, o direito, a política e suas instituiçóes, a arte ou a filosofia) a partir da tensão dialética entre subjetividade e objetividade. Pode-se definir seu método como "ontológico-genético", na medida em que procura mostrar a estratificação progressiva das atividades do sujeito (por exemplo: atividade utilitária, atividade hedonista e atividade estética), indicando as transiçôes e mediações, até circunscrever a especificidade de cada uma em função do papel que desempenham na sua fenomenologia da vida social. Benedetto Croce construiu também uma "filosofia do espírito", fundamentada na circularidade das atividades da consciência (o útil, ou la vitalità, l'arte, la volontà pratica e l'attività concettualle ou riflessiva), mas seu postulado de base é uma "psicologia transcendental", fundada no a priori e na trans-historicidade das categorias do espírito. Lukács se propóe a colocar em evidência a gênese das próprias categorias fundantes, a partir de suas funçóes específicas na economia do espírito. Seu projeto é, então, aquele que parte em direção a uma "ontologia do ser social", e não a uma "psicologia transcendental”.

Uma linha de clivagem muito clara separa também sua aproximação com a "ontologia fundamental" de Heidegger ou a "ontologia fenomenológica" desenvolvida por Sartre em $O$ ser e o nada. A crítica principal dirigida por Lukács para "o ser-no-mundo" heideggeriano é de ter ignorado o papel fundamental do trabalho, portanto, da troca de substâncias entre a 
sociedade e a natureza, na constituição do Dasein (da realidade humana, nós mantivemos a tradução proposta por Henry Corbin). Não é possível chegar a uma verdadeira teoria da inter- subjetividade, da constituição de um Mit-sein (para utilizar a terminologia heideggeriana) sem levar em consideração a sociabilidade consubstancial do ato do trabalho, portanto sem reconhecer a importância do metabolismo entre sociedade e natureza. Günther Anders observou que o Dasein heideggeriano ignora o impulso primordial da fome, ao colocar em evidência a ausência do mundo das necessidades na fenomenologia do Dasein (ANDERS, 2001). A ontologia do Dasein é para Lukács, como para Anders, como para Herbert Marcuse também, uma forma de "pseudoconcretude", porque ela faz a abstração do verdadeiro enraizamento ontológico da realidade humana e da gênese dialética de suas qualidades específicas. Mutatis mutandis, as mesmas críticas são dirigidas por Lukács à ontologia fenomenológica de Sartre. A fidelidade deste último ao conceito heideggeriano do homem como "ser jogado [...]" (a famosa Geworfenheit), mais exatamente à ideia de pura "contingência" da existência humana, é vivamente contestada por Lukács, que funda sua antropologia filosófica na síntese entre as determinaçóes necessárias e as determinaçóes contingentes na gênese da personalidade.

A resistência ao pensamento do último Lukács é devida, em grande parte, à sua adesão ao que se deve chamar de "realismo ontológico" (que não é senão outra denominação para o conceito de "materialismo"). A transcendência do ser em relação à atividade reflexiva da consciência, portanto a autonomia ontológica do "ser em si" (das Ansichseiende, da qual falam em uníssono Nicolai Hartmann e Lukács), é um postulado filosófico que foi vivamente recusado, entre outros, por Adorno, mas também por Merleau-Ponty, que viram aí um retorno a uma ontologia pré-crítica prékantiana ou pré-hegeliana.

Em seu curso ministrado durante o ano universitário de 1960-1961 na Universidade de Frankfurt sob o título Ontologia e Dialética (o registro foi publicado em 2002, como o sétimo volume dos escritos póstumos), Adorno se autodeclarou solidário a Heidegger, seu grande adversário na época, no repúdio infligido à ontologia realista de Nicolai Hartmann (ADORNO, 2002, p.14). Mas há mais de dez anos, ao colocar no papel suas reflexóes críticas sobre o texto dirigido por Lukács à Carta sobre o humanismo, sob o título Heidegger redivivus, Adorno acreditava detectar na dualidade ser- 
consciência, afirmada por Lukács, um deslocamento em direção a um pensamento não dialético (ADORNO, 1986, p. 252-256).

Lukács tomou conhecimento tardiamente dos grandes trabalhos ontológicos de Nicolai Hartmann (depois de terminar sua Estética, em 1960), mas ele percebeu imediatamente o que os aproximava. O autor de Zur Grundlegung der Ontologie e de Der Aufbau der realen Welt se revelou um aliado de peso para sua própria crítica da fenomenologia de Husserl e do pensamento do ser de Heidegger. A escola de Frankfurt em seu conjunto manteve-se impassível à virada ontológica da filosofia, defendida por Hartmann. A desconfiança de Horkheimer e Adorno a respeito do próprio conceito de "ontologia" é bem conhecida. No seu curso Ontologia e Dialética, Adorno afirma que Hartmann pratica uma interpretação estática da dualidade sujeito-objeto, ao atribuir ao objeto uma autonomia ontológica que faria abstração do trabalho mediador da subjetividade. Ele havia formulado dez anos antes, como é sabido, a mesma crítica ao materialismo dialético de Lukács, identificando em seu realismo ontológico uma reificaçâo do pensamento (e, no entanto, Adorno se considerava ele mesmo como um materialista dialético).

As razóes filosóficas profundas que determinaram Lukács a se desligar de sua obra de juventude História e consciência de classe lhe escapavam. Admitir a transcendência do ser em relação à atividade reflexiva da consciência e identificar o ser com a objetivação (die Gegenständlichkeit), segundo a famosa tese de Marx, exposta nos Manuscritos econômico-filosóficos, "[...] ungegenständliches Wesen ist ein Un-wesen" (um ser não objetivo é um não-ser), não tem nada a ver com qualquer reificação do pensamento. Longe de praticar uma reinterpretação estática e fixa da dualidade sujeitoobjeto, Lukács fundamenta seu pensamento sob a tensão dialética entre subjetividade e objetividade. A Ontologia do ser social, síntese de sua visão filosófica, é construída de uma ponta a outra sobre o par categorial teleologiacausalidade, e a posição teleológica (a teleologische Setzung) aparece aí como o centro irradiador da vida social. Encontra-se, pois, longe do "objetivismo" filosófico denunciado por Adorno. É significativo que os representantes da Escola de Frankfurt, de Horkheimer e Adorno a Habermas e Alfred Schmidt, tenham permanecido em silêncio diante dos resultados da reflexão ontológica do último Lukács (mesmo considerando que os dois primeiros não puderam conhecer a Ontologia do ser social, publicada em sua integralidade após o 
falecimento de ambos, as Conversas de Lukács com Abendroth, Kofler e Holz, publicadas pela Rowohlt em $1967^{1}$, já mostravam uma ideia muito clara acerca da orientação geral da obra). Mais recentemente ainda, nas notas que acompanham o texto Ontologia e Dialética, Rolf Tiedemann, o editor dos escritos de Adorno e Walter Benjamin, fala com condescendência do pensamento de Hartmann, considerado como um retorno ao "realismo ingênuo", e não deixou de mencionar o interesse do último Lukács por este pensamento (ADORNO, 2002, p. 349). É necessário perguntar se os representantes da Escola de Frankfurt e seus discípulos compreenderam o sentido de "ontologia crítica" de Hartmann, do qual o programa foi retomado e desenvolvido por Lukács a partir do pensamento de Marx (mais ou menos desconhecido por Hartmann); a própria denominação "ontologia crítica2" (HARTMANN, 1958, p. 268-313) mostra bem que Hartmann integrou em seu pensamento resultados da crítica kantiana ao mesmo tempo em que se opôs decididamente, como fará também, mutatis mutandis, Adorno, ao transcendentalismo kantiano, mais precisamente na tese sobre a função constitutiva da subjetividade na articulação do mundo.

Jürgen Habermas, que sempre sublinhou a importância do livro de Lukács História e consciência de classe em sua formação como pensador (como Adorno e Horkheimer fizeram à sua maneira), foi o único a manifestar certa compreensão do prefácio de Lukács que acompanhava, em 1967, a primeira reedição do livro na língua original. Trata-se, portanto, de um texto fundamental, no qual Lukács explica a virada ontológica de seu pensamento e expóe as razóes que a determinaram, recolocando em discussão o andaime conceitual de seu livro mais célebre (LUKÁCS, 1967, p. 11-41). Em uma longa nota ao fim do capítulo intitulado Von Lukacs zu Adorno: Rationalisierung als Verdinglichung ("De Lukács a Adorno: a racionalização como reificação"), do seu livro Teoria da Ação Comunicativa, Habermas expressa sua concordância com a correção feita por Lukács a respeito da "sobre-hegelianização de Hegel" (ein Überhegeln Hegels) praticada em História e consciência de classe. De fato, ele não poderia subscrever o argumento de Lukács que em sua juventude enxergava no proletariado a encarnação da identidade sujeito-objeto na história (reminiscência hegeliana e schellingiana enxertada no interior do marxismo), porque ele mesmo estava comprometido com um empreendimento de "desmitologização" do marxismo e da reconstrução do materialismo histórico, emancipado 
da tutela de uma "filosofia da história" do tipo hegeliano-marxista. Mas a concordância de Habermas com o pensamento de Lukács se limitava a este único ponto (como ele sublinhava, aliás, expressis verbis) (HABERMAS, 1982, p. 487-488).

Enquanto Lukács se orientava em direção a uma reconstrução do pensamento de Marx, fiel a uma fenomenologia da subjetividade e sob uma base rigorosamente materialista (na qual havia o peso da categoria de causalidade, ausente na reflexâo de Habermas), e em direçâo a uma valorização do conceito de gênero humano destinado a assegurar um fundamento ontológico ao movimento de emancipação (a herança da Fenomenologia do espirito e da dialética hegeliana foram integradas de maneira crítica), Habermas, ao contrário, queria se desvincular do pensamento totalizante do "hegeliano-marxismo" (incluso o conceito de Gattungsmässigkeit, de especificidade do gênero humano), e buscava apoio em Kant e Max Weber, no pragmatismo de Pierce ou de Mead, na filosofia analítica ou na "virada linguística". Se Habermas, ao conhecer em maio de 1966 (via Agnès Heller) o projeto lukacsiano de uma ontologia do ser social, o tinha rejeitado, é porque ele não percebeu a necessidade de fundamentar o materialismo histórico sob uma teoria geral das categorias do ser (id est: sobre uma ontologia). A concepção eminentemente historicista da sociedade, compartilhada pela Escola de Frankfurt, lhe parecia incompatível com o retorno à grande filosofia especulativa, às ambiçóes universalistas. $\mathrm{O}$ grupo de discípulos reunidos na época em torno de Lukács (Heller, Feher, Vajda e Markus), primeiras testemunhas da gênese da Ontologia, se mostrou, entretanto, sensível aos argumentos de Habermas; no texto Aufzeichnungen für Genosse Lukács zur Ontologie, publicado dez anos mais tarde, em 1975, eles demonstram uma incompreensão total das intençóes reais da obra (FEHER, 1986, p. 209-254). ${ }^{3}$

Lukács percebeu a necessidade de voltar à teoria aristotélica das categorias, à dialética da dynamis e a energeia, do poder e do ato, a fim de dar uma fundamentação ontológica sólida ao conceito marxista de práxis. Se ele identifica no trabalho a célula geratriz (a Urphänomen) da vida social, analisando a maneira pela qual as objetivaçóes mais complexas e mais sofisticadas retomam o modelo da relação sujeito-objeto forjada pelo trabalho, isso não significa reduzir a vida social ao "paradigma do trabalho" (como Habermas parecia pensar e como claramente Agnès Heller lhe faria 
a crítica). Seu objetivo era demonstrar como a diferenciação progressiva da vida social em uma multiplicidade de complexos heterogêneos se enraíza nesta atividade originária que é o trabalho.

O que há, pois, de obsoleto nesta abordagem que, visando a dar fundamentaçóes sólidas ao trabalho da subjetividade, à teleologia na multiplicidade das estratificaçóes (teleologia econômica, estética ou ética), descobriu que a ontologia como pensamento do ser e de suas categorias (inclusas as categorias modais: necessidade, possibilidade, contingência) se provaria indispensável? Ao fazê-lo, Lukács permaneceu fiel à poderosa reabilitação do conceito de totalidade exposto em sua obra de juventude História e consciência de classe (ou seja, ao princípio hegeliano: das Ganze ist das Wahre, a totalidade é a verdade, vivamente recusada pela dialética negativa de Adorno), mas ele ancorava-se desta vez em uma interpretação genético-ontológica do ser, ou cada categoria é vista em seu surgimento histórico e na sua função específica na economia do ser. Habermas, como antes dele Adorno e Horkheimer, concebiam o conceito de "reificação" (Verdinglichung) como algo fértil, reservando, assim, sua admiração apenas pelo Lukács de História e consciência de classe.

A Ontologia do ser social coloca sempre o conceito de reificação em papel de destaque, e, sobretudo, o conceito mais amplo de alienação (Entfremdung), objeto do último grande capítulo da obra, mas aí ele se encontra articulado em uma fenomenologia da subjetividade infinitamente mais vasta e mais complexa, que reconhece também as atividades de objetivação (Vergegenständlichung) e de exteriorização (Entäusserung) ${ }^{4}$, completamente ausentes em História e consciência de classe (as quatro categorias, bem distintas, estão, a propósito, completamente ocultas, e, não percebidas pelo marxismo althusseriano, cego que é em relação ao trabalho da subjetividade, enquanto a Crítica da razáo dialética de Sartre teve o mérito de se interessar ao menos por uma parte delas).

Inflectindo seu pensamento em um sentido ontológico, Lukács buscou apoio na ontologia de Nicolai Hartmann, não na "ontologia fundamental" de Martin Heidegger, e compreendem-se perfeitamente suas razóes. Hartmann foi o primeiro filósofo importante a interrogar de maneira fortemente crítica o postulado do pensamento de Heidegger em Sein und Zeit. Em seu livro Zur Grundlegung der Ontologie (Contribuição à fundação da Ontologia), publicado em 1935, ele se indaga sobre a legitimidade de Heidegger em 
fixar como objetivo primordial da ontologia a resposta sobre a questão do "sentido do Ser". Como bom aristotélico, ele lembra a Heidegger que, antes de levantar a questão do "sentido do Ser", é preciso elucidar a questáo do ser simplesmente; a questão do "sentido" só pode se colocar em função da existência de um sujeito (por exemplo, "um sujeito lógico postulado") ou, segundo Hartmann, o Ser do ente permanece em uma indiferença soberana a respeito do que ele pode ser "für jemand" (para qualquer um), incluindo o Dasein (HARTMAN, 1965, p. 41-42).

Pode-se imaginar a satisfação de Lukács ao ler estas linhas. A prioridade dada por Heidegger à categoria de Jemeiningkeit (posse) é para Hartmann a expressão da Daseinsrelativität praticada por Heidegger, incompatível com uma verdadeira trans-subjetividade do Ser. Crítico rigoroso do teleologismo na interpretação do mundo, Hartmann criticou de modo severo até o conceito de forma substantialis em Aristóteles ou o conceito de "razão universal" (Weltvernunft) em Hegel.

Questionou ainda de modo simétrico o determinismo ou o "necessitarismo", mais precisamente a absolutização da categoria de causalidade. Lukács estava convencido de que o marxismo canonizado pela vulgata da II e da III Internacionais estava marcado até a raiz por estas duas graves malformações ontológicas (daí, por exemplo, a interpretação teleológica ou determinista da "necessidade do socialismo", vivamente contestada na Ontologia). Hartmann se apresentava, entáo, como um aliado precioso em um combate bastante rude para livrar o pensamento de Marx das escórias do teleologismo e do determinismo, e de dar à história sua complexidade e seu caráter aberto.

Nicolai Hartmann defendeu energicamente a tese de autonomia ontológica da natureza, com suas inumeráveis cadeias causais, em relação às numerosas atividades teleológicas do homem. Lukács se reencontrou plenamente na Filosofia da natureza (1950) de Hartmann, obra que se tornou um bloco errático na paisagem filosófica de sua época (tanto que vai de encontro à fenomenologia, às filosofias da existência ou da filosofia analítica, que se desinteressariam soberanamente da ontologia da natureza). Outra obra de Hartmann, o pequeno livro intitulado Teleologisches Denken (publicado postumamente em 1951), também o marcou bastante, reforçando-lhe a ideia de que uma ontologia do ser social deve se fundamentar sobre uma ontologia da natureza, como prévia e necessária, e não identificar as leis da sociedade 
com aquelas da natureza (empreendimento impossível), mas circunscrever de maneira rigorosa sua heterogeneidade qualitativa. O "sociocentrismo" de História e consciência de classe, que em uma passagem célebre contestou a existência de uma dialética da natureza, se encontrava, assim, ultrapassado.

Mas Lukács se distancia de Hartmann em um ponto essencial, que ele não deixa de sublinhar no capítulo que lhe é dedicado na parte histórica de A Ontologia; segundo ele, o autor de Der Aufbau der realen Welt se mostrou muito pouco sensível à gênese das categorias ontológicas, às transiçóes dialéticas de um nível ontológico a outro, em particular ao papel primordial do trabalho na passagem do físico ao psíquico. A interação estreita entre trabalho e a gênese da linguagem, era para Lukács, uma evidência. E a antropologia genética de um Arnold Gehlen, por exemplo, que constitui o peso decisivo da Handlung (da ação) na passagem da animalidade à humanidade (sem esquecer seus estudos sobre os instintos, sobre os fundamentos biológicos das condutas especificamente humanas ou sobre a cooperação dos sentidos), acabou por reforçar sua posição.

O método ontológico-genético praticado por Lukács em suas duas obras de síntese, A Estética e A Ontologia do ser social, se propóe identificar as transiçóes capilares de um nível ontológico mais simples a um nível ontológico mais complexo, fixando com precisão as ligaçóes intermediárias. A questão da gênese ocupa um lugar preponderante, porque o surgimento de diferentes níveis com suas categorias específicas intervêm a partir da dialética interna dos níveis anteriores. Não significa somente detectar a transição da animalidade à humanidade (tendo a ação pelo trabalho como conexão decisiva), mas também e, sobretudo, da passagem das formas elementares de troca de substâncias entre sociedade e natureza (o trabalho) às formas de intersubjetividade cada vez mais complexas, nas quais surge, por exemplo, "a voz da consciência” (das Gewissen), portanto, a consciência moral ou as representaçóes imaginárias dos conflitos sociais (as ideologias na multiplicidade de sua estratificação).

A vocação universal do projeto é evidente. O estabelecimento de uma ontologia do ser social era o prelúdio indispensável da ética (assim é, pois, devido a razóes teóricas profundas que Lukács começou na última etapa de seu percurso intelectual a redigir a Ontologia do ser social, antes de se dedicar à última grande obra de síntese, que deveria ser $A$ Ética, e que restou sob forma de rascunho). Com A Estética, redigida entre 1957 e 1960 e publicada em 
1963, indicou com precisão a construção de três componentes solidamente lapidados. Pode parecer paradoxal que Lukács tenha elaborado A Ontologia após ter concluído $A$ Estética. A ordem lógica poderia ter sido o inverso. A verdade é que as condiçôes desenvolvidas na Estética são constantemente sustentadas por uma visão de conjunto de caráter ontológico (a teleologia estética tem como pano de fundo a totalidade das atividades humanas, a magia e a religião até a ciência), também no horizonte de $A$ Estética se configura sem cessar $A$ Ética, a ponto de ter um capítulo especial consagrado às aproximaçóes entre as duas, intitulado justamente de: Zwischen Ethik und Ästhetik (Entre ética e estética) (LUKÁCS, 1963, 576-606). ${ }^{5}$

Pode ser mesmo, ainda, que o trabalho em $A$ Estética tenha lhe revelado a necessidade de consolidar o edifício, acrescentando-lhe uma ontologia como prelúdio indispensável à ética, ou seja, que o projeto de construir um verdadeiro sistema filosófico tomou forma na medida em que suas pesquisas na área da Estética avançaram.

Assim, Lukács se pôs como tarefa propor uma interpretação coerente do conjunto das categorias da existência, elaborando "uma Ontologia, uma Estética e uma Ética", ainda que esta última tenha permanecido sob forma de rascunho. É precisamente isto que torna o seu pensamento singular no interior da filosofia do século XX: o projeto totalizante, sinônimo de um sistema homogêneo e omnicompreensivo. No momento em que o pensamento pós-moderno não cessa de repetir a obsolescência das "grandes narrativas" e de cultivar a desconfiança contra o pensamento categorial, e finalmente, contra também um pensamento simplesmente coerente, Lukács fundamenta uma de suas últimas construçôes sistemáticas em filosofia. (Richard Rorty, por exemplo, mistura sem qualquer inibição Dewey, Heidegger, Wittgenstein e Derrida para destruir toda a ideia de sistema e fazer avançar um pragmatismo sui generis; (resta saber o significado de pragmatismo.)

Aqueles que se engajaram na mesma direção não puderam se sustentar se comparando com o que Lukács conseguiu: Hartmann, por exemplo, cuja teoria da história, exposta em Das Problem des geistigen Seins (1933), é muito convencional aos olhos de Zur Ontologie des gesellschaftlichen Seins; Adorno, que começou com uma obra de síntese filosófica, a Dialética negativa, antes de elaborar uma Teoria Estética (seu caminho é inverso ao de Lukács), mas jamais sonhou com uma ontologia, cujo próprio princípio 
ele recusava; Ernst Bloch, o único que teve a ambição de coroar sua obra com uma ontologia, Experimentum Mundi, cuja ideia lhe foi talvez inspirada pela iniciativa de Lukács ${ }^{6}$, entretanto é difícil o registro de uma estética ou de uma ética sistemáticas.

Retornando à primeira grande obra de síntese de Lukács, A Estética, pode-se dizer que ela fornece o exemplo maior do método genéticoontológico. Lukács introduziu nesta obra as categorias da "vida cotidiana" e do "pensamento cotidiano" (das Alltagsleben e das Alltagsdenken), a fim de definir a gênese das atividades superiores do espírito, a arte e a ciência. As objetivações cada vez mais complexas da consciência são, então, tomadas em sua emergência necessária, tendo como pano de fundo a troca de substâncias entre a sociedade e a natureza. As virtualidades universais do pensamento de Marx encontram, então, sua realização, graças ao enorme trabalho teórico de um filósofo convencido que estava de que o pensamento marxiano não é simplesmente uma teoria econômica.

O poder heurístico e a originalidade de Lukács se tornam evidentes se compararmos seu projeto a outro grande trabalho teórico de nosso tempo, "a ontologia fundamental", esboçada por Heidegger em seu livro Sein und Zeit, e que devia ser suplantada ulteriormente pelo pensamento do Ser. Pode-se efetivamente ler $O$ ser e o tempo como um grande tratado da gênese ontológica das categorias do ser, desde o ser-substancial ou ser-soba-mão (Vorhandenheit), por meio da "usabilidade" ou ser-que-porta-a-mão (Zuhandenheit), até os "existenciais" constitutivos do Dasein (o Cuidado, o Seóv, o ser-jogado, etc.). Mas o método heideggeriano não tem nada a ver com um método ontológico-genético fundamentado na tensão dialética entre subjetividade e objetividade (sua ambição declarada era na verdade de abolir a dualidade sujeito-objeto), na medida em que ele reivindica o apriorismo fenomenológico, a intuição categorial (a famosa kategoriale Anschauung husserlienne) como pedra de toque.

Já identificamos há bastante tempo o pouco espaço dado por Heiddegger em $O$ ser e o tempo à natureza e à sua autonomia ontológica na descrição fenomenológica do ser-no-mundo (a mesma observação pode ser feita a propósito de $O$ ser e o nada de Sartre). Mas pode-se chegar a uma verdadeira "analítica existencial da realidade humana" sem levar na devida conta os condicionamentos físicos e biológicos (afirmou-se, neste sentido, o caráter "assexuado" do Dasein heideggeriano) e, sobretudo, sem levar 
em consideração a ação das cadeias causais da natureza sobre as múltiplas atividades teleológicas do homem, que é constantemente desafiado por elas e obrigado a fornecer respostas? A categoria da causalidade simplesmente não é reconhecida em $O$ ser e o tempo. $\mathrm{O}$ mundo objetivo não existe senão em função do que se chama o pragmatismo do Dasein (cf. neste sentido a obra esclarecedora de Mark Okrent, Heidegger's Pragmatism, Cornell University Presse, 1988). Karl Löwith foi um dos primeiros a observar que o ser-no-mundo heideggeriano fazia a abstração da autonomia ontológica do cosmo e da transcendência da natureza em relação ao vivido existencial.

Em 1969, por ocasião do $80^{\circ}$ aniversário de Heidegger, seu antigo discípulo o lembrava o quanto sua "hermenêutica da faticidade" estava privada da poderosa presença da natureza na imanência mesmo da realidade humana. Presente à reuniáo de aniversário, o autor de $O$ ser e o tempo ouviu sem nenhuma reação as severas críticas endereçadas à sua obra maior. Ele deveria ter ficado muito surpreso ao ouvir Löwith lhe falar sobre a significação biológica da morte (anterior a toda consideração existencial) ou do papel do sono na constituição biológica do homem, prova que a existencialidade da realidade humana não se reduz ao estado de vigília. A existência do cosmo, dizia Löwith ao seu mestre, não se deixa dissolver no Umwelt (o mundo ambiente), de acordo com a "analítica" do Dasein, ou ainda, o "solipsismo transcendental”, do qual falava Günther Anders, não pode reconhecer a autonomia ontológica da natureza.

Assim, o pensamento heideggeriano da "existência" (identificado no Dasein) foi questionado em seus próprios fundamentos. O discípulo não teve receio de apontar as fortes limitaçôes de $O$ ser e o tempo. Löwith chegou mesmo a citar em sua comunicação uma carta que Heidegger lhe havia endereçado em 1927 e onde afirmara que era impossível identificar a especificidade da realidade humana a partir de entidades como a Natureza e o Espírito: "a única aproximação válida era a existencial". Mas quatro décadas mais tarde, o antigo discípulo tornou-se seu crítico, e relembrava que a natureza é uma presença primordial e incontornável, e que a dialética existencial apenas pode se afirmar assumindo os constrangimentos impostos pela natureza (LÖWITH, 1969, 276-289).

O conceito marxiano de troca de substâncias entre sociedade e natureza (der Stoffwechsel der Gesellschaft mit der Natur) é a pedra angular da Ontologia do ser social de Lukács. A sociabilidade está presente aí como 
uma dimensão consubstancial à realidade humana, mas que não pode se desenvolver sem assumir os constrangimentos impostos pela natureza (as relaçóes de produção apoiadas sobre as forças produtivas) e se afirmando por meio das atividades teleológicas cada vez mais complexas.

A prioridade ontológica da economia (forma primordial de troca de substância entre a sociedade e a natureza) não significa de modo nenhum a ocultação das outras formas de intersubjetividade, que se desenvolvem em função das finalidades específicas, como a política e o direito, a moral e a ética. E Lukács segue o combate em duas frentes: de um lado, ele rejeita toda forma de reducionismo, isto é, sacrificar a heterogeneidade dos diferentes complexos sociais a uma causalidade econômica concebida de forma monolítica; de outro, ele recusa a interpretação logicista-teleológica da vida social, que negligencia o papel das transiçóes nas passagens de um complexo a outro, abolindo, assim, a questão da gênese. Seu projeto visa a uma descentralização do espírito, ao evidenciar como mesmo as atividades mais sutis e mais refinadas da consciência (a atividade estética ou a atividade moral) só se tornam plenamente inteligíveis a partir do conjunto do processo de produção e reprodução da existência humana. Ele dedica, por exemplo, em sua Estética, um capítulo ao problema do agradável (das Angenehme), portanto à atividade hedonista, pois, para marcar a diferença específica da atividade estética, não se pode ignorar o papel intermediário da atividade eufórica dos sentidos entre o mundo da pura utilidade (das Nützliche) e a atividade estética propriamente dita.

A famosa clivagem estabelecida por Kant na Análise do belo da Crítica do juizo entre "o agradável" e o "belo" lhe parecia muito abrupta, porque, sem negar sua heterogeneidade qualitativa (ao contrário, sublinhando-a), ele tenta colocar em evidência as transiçôes genéticas de um nível a outro. A consciência moral, por sua vez, não restaria mais no isolamento da autarquia pura dos "imperativos categóricos" e do mundus noumenon. Na Ontologia, ele refuta o transcendentalismo absoluto da razão prática kantiana, mostrando que os imperativos morais não são compreensíveis se não levarmos em conta a multiplicidade das exigências humanas, portanto, também as zonas intermediárias entre a atividade econômica pura e a atividade ética pura (a política e o direito, por exemplo). Lukács se apoia também, como ele o fez em seu livro O jovem Hegel, na crítica hegeliana ao formalismo da ética kantiana (LUKÁCS, 1954, p. 342-343) 
[...] o exemplo kantiano do dinheiro deixado com alguém (não se deve tocar no dinheiro que lhe foi confiado) foi utilizado por Hegel para mostrar que náo podemos deduzir os imperativos morais do formalismo puro da consciência transcendental, mas é preciso recolocá-los no contexto da vida real.

De modo mais geral, Lukács se referia, com o objetivo de sustentar sua abordagem ontológica, às críticas severas de Hegel, que considerava muito brutal a ruptura praticada por Kant entre Sollen (dever-ser) e Sein (ser): ou seja, não poderíamos compreender o Sollen fazendo a abstração da sua gênese no processo de produção e reprodução da vida. A gênese das múltiplas intencionalidades da consciência, até as suas formais mais sutis, se encontra no centro da Ontologia do ser social. Se Hegel era para Lukács uma referência central, isso não significa que ele não tenha tomado a devida distância lá onde o hegelianismo lhe parecia não corresponder às exigências imprescritíveis da consciência individual: se Kant não havia distinguido a moralidade (die Moralität) da eticidade (die Sttlichkeit), Hegel, no entanto, teria sacrificado em demasia a primeira à segunda, ocultando, assim, a irredutibilidade da práxis moral (LUKÁCS, 1986, p. 64-65).

Uma das maiores contribuiçóes de Lukács para a renovação do materialismo histórico é ter enfatizado a assimetria e a heterogeneidade que se manifestam no desenvolvimento dos diferentes complexos sociais. A tese de Marx sobre o caráter desigual do desenvolvimento da sociedade se encontra, assim, plenamente valorizada, mas nós acreditamos não nos enganarmos descobrindo aí também um eco da ontologia de Nicolai Hartmann. O filósofo alemão combateu vigorosamente, desde seus primeiros escritos de caráter ontológico, "o erro da homogeneidade" (o objetivo crítico, sobretudo, era a methexis platônica, a teoria da participação das coisas às ideias), fazendo valer o caráter heterogêneo das diferentes camadas do real. Já na Estética, Lukács também argumentava a respeito da "homogeneização dogmática" do real na doutrina platônica das ideias. ${ }^{7}$ Tanto em um autor quanto no outro, o propósito era combater a sujeição do real à atividade homogeneizante do pensamento lógico, mostrando que a emergência das categorias obedece a uma lógica imanente, que não fica nada a dever à transcendência da razão ou das ideias.

A heterogeneidade é a expressão conceitual desta diversidade irredutível das categorias do real. A célebre lei dialética formulada por Hegel: 
identidade da identidade e da não-identidade, considerada por Lukács como a aquisição mais importante da dialética hegeliana, exprime a mesma realidade. Hartmann combateu não somente "o erro da homogeneidade", mas também "o erro da racionalidade", a fim de sublinhar a heterogeneidade do real em relação ao esquematismo lógico (o erro de Aristóteles teria sido o de identificar a forma dos fenômenos, a forma substantialis, com a essência lógica, que não é nada mais que sua abstração, seu condensado ideal).

Lukács, defensor intratável da razão, em seu livro de combate $A$ destruição da razão, na Ontologia colocou em pauta exaustivamente o que ele denominou de "racionalismo excessivo" (überspannter Rationalismus), no sentido de impedir o sacrifício do real e de suas categorias constitutivas à atividade redutora do esquematismo lógico. A legalidade interna dos diferentes complexos sociais obedece uma lógica própria, que é heterogênea em relação àquela dos outros complexos. A arte e a moral possuem, respectivamente, uma teleologia específica, que não pode ser reduzida à intencionalidade da atividade econômica ou política. Donde o caráter assimétrico das diferentes "posições teleológicas" (teleologische Setzungen). Elas não caminham no mesmo passo, e pode ocorrer que o progresso econômico seja acompanhado de uma regressão ou mesmo de uma atrofia dos valores morais. Lukács lembra, a título de exemplo literário, a clarividência de Balzac em seu romance César Birotteau, no qual mostra que Popineau, a nora de Birotteau, representa uma fase do capitalismo mais desenvolvida e mais eficiente, mas, que do ponto de vista ético, evidencia uma clara regressão em relação à força moral de seu sogro.

A tese lukacsiana sobre a heterogeneidade dos diferentes complexos sociais e sobre a irredutibilidade dos níveis superiores aos níveis inferiores lembra, inevitavelmente, as consideraçóes de Max Weber sobre o politeísmo de valores. Mas enquanto o sociólogo alemão fazia do conflito de valores no mundo dessacralizado da modernidade um dado trágico (esta tese marcou bastante Karl Jaspers, que buscava a solução na existencialidade do sujeito e na sua pura interioridade, enquanto Heidegger denunciava em sua "dessacralização" um "encantamento" - eine Verzauberung - e buscava a saída no culto do Ser e do Evento), Lukács acreditava encontrar a solução na concepção genético-dinâmica da substância humana, que chega, por meio de suas múltiplas objetivaçóes - incluídas as mais altas (as grandes açóes 
éticas, as obras de arte, as sínteses filosóficas -, a fixar de maneira durável as aquisiçôes do gênero humano.

A pedra angular da concepçâo lukacsiana da subjetividade é a linha de clivagem que separa o mundo da "particularidade" (as inclinaçóes e as necessidades estritamente individuais, aquelas designadas por Kant, com um termo ligeiramente pejorativo, como "patológicas") do mundo das objetivaçôes superiores da consciência, no qual a subjetividade se eleva ao nível do gênero humano (segundo o princípio tua res agitur, porque cada indivíduo pode se reconhecer no gênero quando se trata das objetivaçóes que portam a marca distintiva da universalidade). As alegrias que são enquadradas pela categoria do agradável são bem distintas da sabedoria epicurista, que implica a moderação das pulsóes e das inclinaçóes, a ataraxia.

A figura do sábio estoicista ou epicurista, o amor dei intellectualis de Spinoza, a concepção goethiana da personalidade harmônica, figuram entre as referências invocadas para marcar a transcendência do gênero humano em relação à pura particularidade. A fenomenologia da criação artística oferece a Lukács um terreno particularmente favorável para explicitar esta concepção ontológico-genética da subjetividade. Em suas longas investigaçóes sobre as mediações entre a subjetividade cotidiana e a subjetividade estética (entre a "realidade da experiência vivida" - Erlebniswirklichkeit - e o "vivido normativo" - normatives Erlebnis - a obra de arte, segundo a terminologia de sua estética de juventude, a Heidelberg - Äshtetik), Lukács interroga particularmente em $A$ Estética uma categoria de produçóes situadas em uma zona intermediária entre os produtos do diletantismo ou da pura virtuosidade (sem esquecer os produtos kitsch) e as verdadeiras obras de arte. Trata-se da Belletristik (a beletrística), produçóes de fato honoráveis, que têm a aparência de uma produção estética, mas que na realidade são desprovidas da ênfase transcendental que lhes elevaria ao nível de arte.

A subjetividade que se exprime em sua imanência não possui a marca distintiva da universalidade, não chega ao nível da consciência-de-si do gênero humano. Benedetto Croce já havia fornecido em sua última grande obra de estética A Poesia (publicada em 1936) uma análise magistral da clivagem que existe entre "a poesia", a "não poesia" e a "antipoesia", entre a "expressão oratória", "a expressão literária" e "a expressão poética". Deste ponto de vista, Lukács se encontra em perfeita convergência com Croce: ele mostra como obras como Frau Jenny Treibel, de Theodor Fontane, Le Nègre 
du Narcisse ou Sous les yeux d'Occident, de Joseph Conrad ${ }^{8}$, são produçóes de beletrística, expressóes de uma visão moral ou de uma tendência social respeitável, mas privada da transcendência da pura humanidade, enquanto Effi Briest e Irrugen, Wirrugen, do mesmo Fontane, ou Lord Jim e Typhon, de Conrad, se elevam ao nível da grande literatura graças à "l'accento inconfondibile" (Croce) da humanidade integral. Para estabelecer clivagens assemelhadas na música, Lukács cita um texto bastante cáustico de Alban Berb, Réponse responsable à une question frivole (escrito em 1926), no qual o eminente discípulo de Schönberg ilustrava por exemplos a rejeição dos verdadeiros valores musicais no momento de sua emergência. Mahler, Bruckner, Debussy ou Max Reger eram quase ignorados pelo MeyersKonversation Lexikon publicado em 1900, em benefício de nomes depois totalmente caídos no esquecimento. O espírito exigente de Berg e, ainda que sobre outro plano, as consideraçóes de Hermann Broch a propósito do kitsch e do "homem kitsch" eram para Lukács como argumentos a favor de uma distinção séria entre a verdadeira arte e seus simulacros.

$\mathrm{O}$ terceiro componente de uma construção solidamente lapidada na qual $A$ Estética e $A$ Ontologia formam as duas outras deveria ser $A$ Ética. O filósofo não teve tempo de escrevê-la, mas podem-se reconstruir seus lineamentos a partir das duas grandes obras que a precedem, e levando em conta, certamente, as notas preparatórias reunidas sob o título Versuche zu einer Ethik, e publicadas em 1994 em Budapeste pelos Arquivos Lukács. Mas, antes de falar de A Ética, é necessário esclarecer o caminho seguido por Lukács, comparando-o com as posiçóes de Martin Heidegger ou aquelas mais recentes de Jürgen Habermas. Como já sugerimos, a concepção ontológico-genética da subjetividade lança uma luz bastante edificante nos limites e falhas da "analítica existencial" heideggeriana. Nós já esboçamos a disparidade entre as duas aproximaçóes em um texto intitulado $A$ concepção de alienação em Heidegger e Lukacs, publicada nos Arquivos de Filosofia (julhosetembro de 1993). Trata-se, agora, de voltar aos fundamentos ontológicos de suas divergências.

$\mathrm{O}$ primeiro que procurou estabelecer aproximaçóes entre $O$ ser e $o$ tempo de Heidegger e o pensamento sobre a subjetividade de Lukács foi um discípulo do primeiro, que mais tarde se tornou um filósofo das matemáticas e teórico da Paraexistenz, Oskar Becker. Com Karl Löwith, Becker esteve entre os ouvintes dos primeiros cursos de Heidegger no começo dos anos 
vinte (mais tarde, professor em Bonn, ele teria entre seus estudantes Otto Pöggeler e Jürgen Habermas). Fiel a Husserl e Heidegger, Becker publicou no fim dos anos vinte na Festschrift dedicada a Husserl (publicada em 1929) um texto bastante singular, Sur la fragilité du beau et le caractère aventurier de l'artiste ${ }^{10}$, no qual ele se mostra particularmente receptivo às teses defendidas por Lukács em seu texto intitulado Die Subjekt-Objekt Beziehung in der Ästhetik (trata-se, na verdade, do capítulo central da estética do jovem Lukács, Die Heidelberg Ästhetik), publicada na revista Logos, em 1917-1918 ${ }^{11}$. Becker se mostrava bastante interessado, entre outros, pela distinção operada por Lukács entre o plano da existência cotidiana, no qual o homem vive disperso na multiplicidade de suas atividades (o nível do der ganze Mensch), e aquele das objetivaçóes superiores do espírito (a arte em particular), no qual as faculdades humanas são reunidas e focalizadas, nível que Lukács chamava com uma expressão emprestada de Schiller der Mensch "ganz" (o homem na sua plenitude intensificada).

Leitor atento de Sein und Zeit, publicado dez anos após o estudo de Lukács, Oskar Becker surpreendeu-se com certas semelhanças entre os dois textos; ele encontrou nas análises de Lukács a paisagem familiar das considerações de Heidegger sobre a passagem da "temporalidade horizontal" do tempo vulgar à "temporalidade extasiada (vertical)" do tempo autêntico, e talvez, sobretudo, as referências à Ganzsein (ser tudo) e Ganzseinkönnen (poder-ser-tudo), presentes na parte final de $O$ ser e o tempo. Pode-se observar que Lukács manteve intacta em sua Estética de maturidade a distinção entre der ganze Mensch da cotidianidade e der Mensch "ganz" objetivada pela obra de arte, porque ela estava fortemente de acordo com sua concepção ontológico-genética de subjetividade.

Se Lukács sempre criticou com tanto vigor Sein und Zeit (e não somente no seu estudo Heidegger redivivius ou em $A$ destruição da razão, mas também em sua Estética e, sobretudo no capítulo sobre o existencialismo de $A$ Ontologia do ser social), é porque, para além das afinidades com a problemática heideggeriana e de seu vivo interesse por certas descrições fenomenológicas do Seóv, do das Man (nos quais ele encontrava, talvez erroneamente, um eco sublimado da crítica marxiana do fetichismo da mercadoria), ele sentiu a incompatibilidade das duas aproximaçôes, a sua e a de Heidegger. A visão de Lukács era claramente oposta à de Heidegger acerca dos seguintes problemas: a transcendência do Dasein, a natureza 
do projeto (Ent-wurf), a Geworfenheit (o ser-jogado) e particularmente a liberdade e seus fundamentos ontológicos. A Ontologia do ser social permitiu retomar o debate lançado anteriormente por Lucien Goldmann, a partir de premissas bastante contestáveis, a propósito das proximidades entre Lukács e Heidegger. Pode-se escolher como ponto de partida um problema ontológico muito particular: a categoria modal da possibilidade, que abre as vias múltiplas em direção a uma confrontação das posiçóes de Nicolai Hartmann, de Martin Heidegger e de Georg Lukács, sem esquecer aquelas de Adorno ou de Habermas.

A categoria da possibilidade desempenha papel central na analítica do Dasein, porque o autor de Sein und Zeit faz da preeminência da possibilidade sobre a efetividade (Wirklichkeit) e sobre a necessidade um traço distintivo da realidade humana em comparação com o "ser-sob-a-mão" (das Vorhandene). Heideger afirma:

Como categoria modal do ser-conduzido-pelamão, a possibilidade significa o que não é ainda efetivo e nem sempre necessário. Tal possibilidade caracteriza o somente possível. Ontologicamente, ela é inferior à efetividade e à necessidade. A possibilidade, como existencial, ao contrário [itálico nosso - N.T.], é a determinação ontológica positiva a mais originária e última do Dasein. (HEIDEGGER, 1941, p. 143-144).

Pouco antes, Heidegger havia escrito: "O Dasein não é um sob-a-mão que possuiria, por outro lado, o dom de poder qualquer coisa, mas ele é primeiramente possibilidade" (HEIDEGGER, 1941, p. 143-144).

A categoria de possibilidade possui um papel central em Luckács na análise da relação entre teleologia e causalidade a propósito do ato de trabalho: se trata, na verdade, nele também, da capacidade de definir a especificidade da existência humana. Lukács partilha deste ponto com a descrição feita por Hartmann da relação entre a "posição teleológica" (die teleologische Setzung) e as cadeias causais objetivas (descrição que retoma o esquema proposto por Aristóteles em sua Metafísica), mas ele vai se opor vigorosamente à defesa de Hartmann das visóes da Escola Megárica contra Aristóteles, a propósito justamente da categoria da possibilidade. 
Lukács sublinha, com não menos energia do que Heidegger, a differentia specifica da realidade humana em respeito aos outros níveis ontológicos, mas ele a procura na relação específica da teleologia das atividades humanas com as redes causais objetivas. Para ele, não se trata de autonomizar a categoria da possibilidade em relação àquelas da efetividade ou da necessidade (como sugere o texto heideggeriano), mas de mostrar o contrário, que a teleologia humana se enraíza sempre na causalidade: a atualização da dynamis, das potencialidades, das latências e das virtualidades do real, que caracteriza a intencionalidade no ato do trabalho, significa ipso facto que a realidade (a Wirklichkeit) é ontologicamente primordial. Nem Hartmann nem Lukacs cogitaram em contestar a prioridade ontológica da realidade ( $\mathrm{da}$ "efetividade") em relação, inclusive, à possibilidade, considerando que se trata da analítica da realidade humana.

Oskar Becker esboçou uma vez, em algum de seus últimos trabalhos, o opúsculo Untersuchungen über den Modalkakül (Pesquisas sobre o cálculo modal, publicado em 1952), uma comparação entre as ontologias de Hartmann e de Heidegger (nós agradecemos ao professor Otto Pöggeler, que chamou nossa atenção para este texto). Ele constrói a análise partindo justamente da categoria de possibilidade e sublinha a ambição de Heidegger de desconcertar a ontologia tradicional, inclusive a de Hartmann, se apoiando sobre uma abordagem renovada da possibilidade.

$\mathrm{O}$ aspecto interessante do texto de Becker reside nas suas consideraçóes sobre um dos "existenciais" privilegiados por Heidegger em sua analítica da existência humana: “o ser-jogado” (die Geworfenheit), que será também objeto de severas críticas de Lukács. Becker se interessou pelas categorias de "projeto jogado" (geworfenen Entwurf) e de "possibilidade jogada" (geworfene Möglichkeit), mas ele se indagou, sobretudo, acerca do estatuto da "necessidade" na "Geworfenheit" heideggeriana. O Dasein é, de um lado, mergulhado na "faticidade", lançado às circunstâncias que ele mesmo não escolheu (ele é, então, disse Becker, submetido à necessidade, em particular ao constrangimento), mas, de outro lado, ele é projeto (Entwurf), núcleo de possibilidades. Dito em outros termos, o que Heidegger denomina de "possibilidades jogadas", Becker chama de uma "necessidade impura" (unreine Norwendigkeit), pois esta, para Heidegger, parece forçada pela contingência, e ele não se dá conta dos verdadeiros condicionamentos da existência humana. 
Becker retorna também ao papel da natureza como subestrutura necessária à existência humana e avança no conceito de "Para-Existenz" para definir as estruturas que não são relativas ao Dasein (nós não podemos parar aqui sobre os aspectos contestáveis do pensamento de Becker, em particular sua tentativa de distinguir sua "Para-Existenz" da esfera do real em Hartmann, recordando somente superficialmente seu compromisso com o racismo nacional-socialista).

A categoria do ser-jogado (Geworfenheit) é útil a Lukács para revelar as tendências profundas da ontologia heideggeriana. Ele questiona com insistência a contingência do ser-jogado, a obscuridade na qual estariam mergulhados, segundo Heidegger, o "de-onde" e "para-onde" da existência humana. "Das pure "dass est ist" zeigt sich, das Woher und Wohin bleiben im Dunkel" (Este puro "que ele é" se mostra, mas seu "de-onde" e "paraonde" restam na obscuridade). Lukács observa que, de um lado, o Dasein heideggeriano está entregue ao mundo da inautenticidade (ele é jogado no Se, das Man), por outro lado, a suposição das possibilidades autênticas resta em uma pura indeterminação, pois seus sinais, segundo Heidegger, estão encobertos pela obscuridade. ${ }^{12}$

A transição da "faticidade" ao "projeto", de "estado de abandono" (Preisgegebenheit) que caracteriza a primeira à autoafirmação de si que caracteriza o segundo, da inautenticidade do Se à "resolução" (Entshlossenheit) que é constitutiva do si autêntico permanecem um enigma em Heidegger. $\mathrm{O}$ modelo de inteligibilidade proposto por Lukács insiste nas mediaçóes entre os dois planos, o primeiro que é o heterocondicionamento da personalidade e, o segundo, da sua afirmação. Seu método ontológico-genético lhe permite indicar a gênese da transcendência do ser humano, a partir do "distanciamento" compreendido pelos atos mais elementares do trabalho, até o controle dos afetos e o surgimento dos atos de autorrealização de si. O ser humano é, para ele, um feixe de possibilidades (Heidegger define o ser humano como "o ser da distância", ein Wesen der Ferne), mas essas emergem sempre, em Lukács, em um contexto concreto, são as "possibilidades concretas", e não as "possibilidades abstratas", segundo a distinção feita por Hegel.

A escolha, segundo Lukács, não surge misteriosamente a partir da "nadidade dos fundamentos" (die Nichtigkeit des Grundes), mas se desenvolve como uma resposta a uma interpelação, como uma decisão a partir de uma 
situação circunscrita. $\mathrm{O}$ conceito de decisão entre alternativas, pedra angular de A Ontologia do ser social - é fundada sobre uma dialética da energeia e da dynamis que parte das latências e das virtualidades existentes na imanência do real e da subjetividade. A negação é sempre uma "negação determinada" (segundo a fórmula de Hegel), e a definição do homem estabelecida por Lukács: "ein antwortendes Wesen" (um ser que responde) exprime bem esta inscrição da escolha entre alternativas no interior das categorias modais do real (necessidade, possibilidade, contingência).

No momento em que o pensamento pós-moderno celebra o "antifundamentalismo" (Rorty, por exemplo), que se compraz nas situaçóes de "indecisibilidade" (Derrida) e em que o marxismo tradicional se limita a definir a liberdade como "consciência da necessidade" (segundo a fórmula de Hegel, retomada mutatis mutandis por Engels), a abordagem do problema da liberdade tal qual se manifesta em $A$ Ontologia do ser social tem certa atualidade. Lukács mostra a insuficiência da definição hegeliana-engelsiana da liberdade como consciência da necessidade, ao valorizar o papel da possibilidade e da contingência (Zufälligkeit) na constituição do ato livre. Ele relembra, a título de exemplo, a maneira pela qual Rafael soube utilizar no Vaticano a contingência desfavorável das formas das janelas para a realização magnífica de seus afrescos, O Parnaso e a Liberação de Pedro. O ato livre não se reduz, pois, à consciência da necessidade, mas implica a valorização das possibilidades e das contingências inscritas na imanência do real. Estamos longe da mistagogia heideggeriana sobre a liberdade como "fundamento do fundamento" ou "abismo (Abgrund) da liberdade humana"; Heidegger desprezava a abordagem categorial dos fenômenos (ela pertencia, segundo ele, à metafísica obsoleta), mas Lukács mostrou que a questão do fundamento somente pode ser resolvida se apoiando sobre as categorias constitutivas do real (a liberdade não é um transcendental, mas uma conquista progressiva da consciência, e seria legítimo falar de um pluralismo das liberdades, diferentes em função dos campos de atividade).

Habermas afirmou, certa feita, que tinha o sentimento de que o pensamento do último Lukács teria sido menos fértil em novos conceitos que o jovem Lukács. No entanto, basta estudar atentivamente a Estética e a Ontologia do ser social para se convencer do contrário. Poderíamos citar, entre tantos exemplos, a dissociação de dois momentos distintos: a objetivação (Vergegenständlichung) e exteriorização (Entäusserung) em cada 
ato, o que permite mostrar a coexistência do gênero (Gattung, resultado da objetivação) e da individualização (resultado da exteriorização) nas múltiplas atividades teleológicas. A polaridade individuação (Einzelheit) - gênero (Gattungsmässigkeit) perpassa a Ontologia.

É nesse contexto que se inscreve a dualidade: gênero humano em si (Gattungsmässigkeit an sich) e gênero humano para-si (Gattungsmässigkeit für sich), que é o ponto culminante de Ontologia. A proliferação das qualidades e das atitudes dos indivíduos que acompanham necessariamente o desenvolvimento da sociedade e seus progressos técnico-econômicos representa para Lukács o estado do gênero humano em-si; o ato de assumir suas qualidades na unidade superior de uma humanitas se torna mestre dele mesmo (ou, segundo a fórmula de Marx, "die menschliche Kraftentfaltung... sich als Selbstzweck gilt" - o desenvolvimento das forças humanas... se torna um fim em si-mesmo), define o estado do gênero humano por-si. A passagem de um a outro é sinônimo da famosa transição do "reino da necessidade" ao "reino da liberdade".

A especulação filosófica de Lukács está sempre imbricada ao seu engajamento sociopolítico. Seu projeto é de edificar uma nova ontologia, disciplina especulativa por excelência, na medida em que, ao visar os próprios fundamentos do ser e de suas categorias, Lukács não se move exclusivamente na esfera da philosophia perennis (como é o caso preponderantemente de Nicolai Hartmann, seu principal apoio e aliado no terreno especulativo.), mas ele persegue também um fim eminentemente ideológico: restituir o pensamento de Marx em sua autenticidade (ele fala de echter Marxismus), aniquilando suas deformações, sua perversão e sua simplificação. A título de exemplo, a questão das categorias modais (necessidade, possibilidade, contingência), capítulo central da ontologia desde a Antiguidade, é abordada pelo autor de A Ontologia do ser social na perspectiva de seu combate contra as interpretaçóes "necessitaristas" da história, pelas quais, aos seus olhos, os pensadores da social-democracia (de Karl Kautsky a Otto Bauer) também se tornaram responsáveis, do mesmo modo que, em outro plano, os marxistas stalinistas.

O calor com o qual Lukács saúda a tese de Nicolai Hartmann sobre a preeminência da realidade (da Wirklichkeit, da efetividade) em relação às outras categorias modais (a necessidade ou a possibilidade como carrochefe) não é um gesto puramente especulativo: se trata, na verdade, de 
um pilar central de sua concepção genético-ontológica do ser, do eixo de sua "dedução das categorias", para retomar a expressão clássica (que seja lembrado o lugar que a dedução das categorias ocupa, por exemplo, nas relaçóes entre Fichte e Kant ou na lógica hegeliana), mas no horizonte de suas consideraçóes sobre as categorias modais se encontra a preocupação de dar ao materialismo histórico a elasticidade e a flexibilidade na sua maneira de apreender a história. Seu protesto contra a sinonímia entre realidade e necessidade, o problema de sua identidade ou de sua náo-identidade, problema eminentemente especulativo, tem como impulso sua vontade de libertar o marxismo do suposto que absolutiza a necessidade na história e que fetichiza suas "leis objetivas". Se ele sublinha que a necessidade é somente uma modalidade da existência da realidade, que não esgota suas determinaçôes (ele pretende oferecer à contingência o lugar que lhe pertence), o centro da gravidade de suas reflexóes não recai tanto sobre a especulação ontológica (não encontramos em seus escritos o equivalente das análises consagradas às categorias modais por Nicolai Hartmann em um livro como Möglichkeit und Wirklichkeit), mas ele se mostra preocupado em apontar as consequências práticas das distorçốes cometidas no plano ontológico.

Se ele se mostra rigoroso com oportunismo da social-democracia, por exemplo, é porque seus teóricos forneceram uma versão do pensamento de Marx que fetichizava a necessidade no encadeamento dos acontecimentos históricos, praticando o fatalismo na apreensão da história: o campo de manobra da subjetividade e sua capacidade de quebrar as cadeias causais dadas modelando as constelações históricas não são concebíveis se não levarmos em consideração as possibilidades e as contingências, portanto, uma ontologia do ser social, bem diferente daquela que absolutiza a necessidade. Nos Prolegômenos e na Ontologia, ele evoca duas deformaçóes do pensamento de Marx, porque acredita na necessidade de combater simetricamente tanto o fatalismo histórico quanto o sectarismo, e exemplifica sua posição por uma referência, que pode parecer um pouco enigmática, à atitude que seu amigo, o marxista austríaco Ernst Fischer, teve em relação a Otto Bauer, o líder da social-democracia austríaca (LUKÁCS, 1984, p. 208).

$\mathrm{O}$ livro de memórias de Ernst Fischer intitulado Erinnerungen und Reflexionen, publicado em 1969 na Alemanha, em Rowohlt, contém efetivamente numerosas páginas sobre as relaçóes de seu autor com o líder social-democrata, em que se encontra um pequeno capítulo que 
reporta uma conversa entre os dois, durante seu último encontro em 1935 (FISCHER, 1969, p. 340-349). ${ }^{13}$ Lukács conheceu essa publicação, que ele apreciou bastante, como resultado de uma carta endereçada a Fischer em 2 de dezembro de 1969, na qual ele acusa o recebimento da autobiografia. Podemos, então, supor que o pequeno parêntese deslocado nos Prolegômenos à Ontologia (c.f. Supra), redigidos justamente no verão de 1970, faz eco às críticas formuladas pelo marxista austríaco a respeito do principal teórico do austromarxismo.

Lukács tinha muito a fazer para dissipar as interpretaçôes "deterministas" e "necessitaristas" do pensamento de Marx. O discurso sobre as "leis de Airan" do desenvolvimento social (Lassale utilizou esta expressão, mas a ideia era muito generalizada entre os "marxistas" da época), no seu ponto de vista, necessitava uma crítica severa. Ele admitiu que se poderíamos encontrar no próprio Marx fórmulas que endossavam tal cientificismo, mas considerava que isso se devia à atmosfera intelectual que dominava em meados do século XIX. A vocação da "ontologia crítica" que ele denominava de promessas e, sobretudo, de uma ontologia do ser social, era a de precisar o funcionamento das categorias da necessidade e da contingência (sem falar da possibilidade) na história do ser, de circunscrever a esfera da ação das "leis", precisando seu caráter tendencial, pois elas funcionam em meio à massa de contingências, de definir a relação entre a heterogeneidade e as diferentes camadas do real ou os diferentes complexos sociais e a homogeneidade instituída pela ação, etc. Compreende-se, então, que ele possui muitos pontos de consenso com as páginas onde Ernst Fischer denunciava o "fatalismo histórico" da social-democracia, caracterizando-a como uma "simplificação do materialismo histórico" e, sobretudo, com o retrato destacado que ele fazia da fisionomia contraditória de Otto Bauer, para quem a força do pensamento e a integridade do caráter se combinavam com a hesitação, aliás, o recuo diante da escolha revolucionária (FISCHER, 1969, p. 250-251, 340). Lukács tomou emprestado de Nicolai Hartmann os instrumentos conceituais para desfetichizar o conceito de "necessidade histórica" e certamente ele foi sensível às considerações do filósofo alemão sobre o caráter relacional da necessidade: as premissas de um encadeamento causal de caráter necessário podem muito bem portar a marca distintiva da contingência. É isto que Hartmann designava pela fórmula da necessidade "se-então" ("Wenn-So" Notwendigkeit), que aparece em Lukács sob forma ligeiramente diferente: "WennDann Notwendigkeit"(HARTMANN, 1995, p. 38-39). 
Quanto ele se dedicou a fazer valer o lugar da singularidade (de Einzelheit) no quadro das categorias que estruturam a vida social, se opondo à hegemonia do "universal abstrato", pode-se deduzir o seu interesse pelo problema da "causalidade estatística", que constitui, por sua vez, o fundamento ontológico do caráter tendencial das leis que governam a marcha da sociedade. $\mathrm{O}$ lugar das contingências não pode ser respeitado, se dissolvermos os fenômenos na lei que lhes subjaz, retirando sua relativa autonomia. Lukács escreveu assim nas páginas finais do capítulo sobre Hartmann de sua Ontologia:

[...] as leis estatísticas têm como pressuposto ontológico certa impossibilidade de deduzir os casos singulares, enquanto casos singulares, da necessidade de sua (jeweilige) totalidade e, por outro lado, a impossibilidade de sintetizar um conjunto qualquer a partir das simples dinâmicas singulares. (LUKÁCS, 1995, p. 465)

Pode-se observar, superficialmente, que a crítica feita por Lukács a Hartmann, de ter ignorado o problema da causalidade estatística e sua importância ontológica, é muito pouco fundamentada (LUKÁCS, 1995, p. 465-466). Uma leitura mais atenta da Filosofia da natureza do filósofo alemão, obra à qual ele, a propósito, atribuiu muitos méritos, teria lhe mostrado que um capítulo inteiro da terceira seção do livro, intitulado precisamente "Klassische und statistische Gesetzlichkeit" (Legalidade clássica e estatística), é dedicado ao problema que o preocupava (HARTMANN, 1950, p. 401-410).

As considerações de Lukács sobre as categorias modais estão perpassadas pela obsessão de relativizar a esfera da ação da necessidade e fazer valer o peso das contingências, e têm como objetivo interditar definitivamente as interpretaçóes "cientificistas" do marxismo, que aprisionam o desenvolvimento da sociedade sob a canga de um encadeamento com sentido único, com o qual o advento do socialismo se dá em um prazo fatal. É suficiente pensar nos debates suscitados pelo livro de Jacques Monod Le Hasard et la Nécessité14 (lançado em 1970): o célebre bioquímico interpretou justamente o marxismo como um "pensamento cientificista", que praticava, segundo Monod, uma universalização arbitrária das leis da dialética, desconfiando da presença incontornável do acaso na história da 
vida. Vinte anos mais tarde, "a querela do determinismo", que assistiu o confronto de cientistas de renome como René Thom, Ilya Prigogine, Isabelle Stengers, Stefan Amsterdamski, etc., girou em torno, principalmente, das relaçóes entre determinismo e casualidade: René Thom, por exemplo, defendeu brilhantemente a causa do determinismo, lançando flechas contra os "adeptos do acaso" e falando da estatística como uma "hermenêutica determinista". Mas em suas conclusóes ele modulou sua posição ao designar as "rupturas da causalidade" como surgimento do acaso (POMIAN, 1990).

Lukács criticou Nicolai Hartmann por não ter formulado uma “ontologia da contingência” (a expressão "Ontologie des Zufalls" aparecia nas páginas finais do capítulo sobre Hartmann da Ontologia) (LUKÁCS, 1995 , p. 464), mas essa objeção tampouco nos parece muito justificada. Hartmann debateu longamente o problema da contingência em seu livro dedicado às categorias modais e mostrou com argumentos convincentes o caráter "problemático" de admitir a contingência como uma categoria ontológica autônoma. Sempre onde ocorrem encadeamentos causais, sua expressão modal é a Realnotwendigkeit (a "necessidade real"), assim, o oposto da contingência pura. Lukács aproveitou bastante, no fundo, as distinçóes formuladas por Hartmann: o filósofo alemão mostrou que a relativização da necessidade é justificada no momento em que se considera o primeiro elo de uma cadeia causal como possuindo um caráter contingente ("tudo o que vem primeiro é contingente", escreveu Hartmann; se aceita como dado - por exemplo, as "constantes" da Física - sem explicá-las pelas causas preliminares). Lukács formulou seu conceito Wenn-Dann-Notwendigkeit (a necessidade se-então), para fazer valer a presença da contingência nos encadeamentos causais de caráter necessário. Ele elogiou Hartmann e seu "senso de realidade" por ter "[...] visto em tudo, mesmo nas necessidades, a ação da contingência, a impregnação do mundo pela contingência” (LUKÁCS, 1995, p. 464) Seu objetivo era de combater a ideia do caráter unívoco do desenvolvimento histórico, relembrando que é suficiente modificar as premissas de um encadeamento causal (por um ato de "instauração teleológica") para obter uma mudança de direção.

Lukács polemizou contra a "ontologia da necessidade", pois ele tinha em mira a desnaturalização stalinista do marxismo, que havia encerrado o desenvolvimento histórico em um esquema linear, construído em torno 
da sucessão imperativa de cinco formações sócio-históricas (a comuna primitiva, o escravismo, o feudalismo, o capitalismo e o socialismo). Contra tal fechamento da história, que desnatura sua complexidade em nome de um esquematismo lógico-teleológico, o autor da Ontologia não deixava de relembrar a ocultação, durante a época stalinista, de uma formação história como o "modo de produção asiático", ao qual Marx atribuiu em seus escritos um interesse particular. Mais globalmente, sobre o terreno ontológico, ele se mostrava aberto a uma crítica do determinismo laplaciano, sem falar do repúdio à doutrina protestante da "predestinação", para ele exemplo de uma absolutização da necessidade; ele recusava no mesmo sentido as filosofias da história do tipo hegelianas, Nas quais o teleologismo privilegiava a necessidade igualmente de maneira indevida. Se ele se mostrava vivamente interessado pelas teorias da Física moderna que substituem a causalidade linear pela causalidade estatística, é porque elas fazem justiça à dialética da necessidade e da contingência, fazendo valer a imprevisibilidade na trajetória dos elétrons. Sobre o terreno do ser social, a relativização da necessidade lhe permitia esboçar a relação justa entre a ação das leis (definidas como conexốes relativamente estáveis na massa dos fenômenos) e a multiplicidade abundante das contingências. Uma página célebre de Marx, em uma carta a Kugelmann a propósito da Comuna da Paris e do papel decisivo na sucessão dos eventos das qualidades particulares dos dirigentes do movimento, é utilizada para contraposição ao "necessitarismo" presente em Engels, quando ele veio a afirmar que uma tendência histórica se impóe de uma maneira incontornável, qualquer que seja a fisionomia individual do personagem que a encarna (seja Napoleão, seja outro general - Moreau, por exemplo - isto resulta no mesmo) (LUKÁCS, 1984, p. 122-124).

O debate sobre as categorias modais deveria levar em conta, também, o uso amplo que Lukács faz das categorias da heterogeneidade e da homogeneidade, visto, sobretudo, que a contingência é definida, seguindo uma longa tradiçáo, como o resultado de uma interferência nas cadeias causais heterogêneas. A ideia da estrutura heterogênea do real, retomada de Nicolai Hartmann, não recebeu, no entanto, em Lukács uma elaboração ontológica suficiente. Tampouco a ideia do caráter homogeneizante da lógica (sem falar das matemáticas) é convincente, ao passo que a fundação ontológica do caráter heterogêneo dos complexos que articulam o real mereceria uma demonstração mais profunda. 
Lukács é o único entre os filósofos contemporâneos que desenvolveu de maneira consequente uma verdadeira filosofia da imanência (a Diesseitigkeit). Não há lugar, no seu pensamento, para nenhum messianismo, para nenhuma intervenção da transcendência; ele se situa, assim, no caminho correto em relação à obra de Marx. Seu esforço no capítulo final de $A$ Ontologia do ser social (dedicado à alienação) foi fixar as mediaçôes que asseguram a transição do gênero humano em-si ao gênero humano para-si, para além das crises, das regressóes e dos impasses da história. Deste ponto de vista, ele se distingue claramente de Heidegger. O próprio Lukács foi o primeiro a falar do "ateísmo religioso" que caracterizaria o pensamento do Dasein. E lendo as páginas de Heidegger sobre o "divino" que surge no si autêntico (cf. Einführung in die Philosophie, o curso de 1928-1929, p. 360-361), ou sobre a proximidade bem grande do pensamento sem-deus do Deus divino (cf. Identidade e Diferença, p. 306), não podemos deixar de dar razão a Lukács. Mas o mais espantoso ainda é que ele se distingue, também do ponto de vista de outros filósofos marxistas. Ele sempre relembrava, por exemplo, das questôes que o separavam do pensamento de seu amigo Ernst Bloch. Uma clivagem se desenhava já entre Geschichte und Klassenbewusstsein e Der Geist der Utopie; permaneceu totalmente indiferente em relação a $O$ princípio da esperança e ele não deixava de ironizar "a autonomia fenomenológica da alma” defendida por Bloch em seu livro Espirito de utopia. O messianismo apocalíptico deste lhe era perfeitamente estranho. Também em relação às Teses sobre a Filosofia da História de Benjamin, ele não teria sido talvez mais gentil. E, caso ele tivesse aprovado a crítica ao oportunismo social-democrata ou do filistinismo do "progresso", ele teria certamente desaprovado o chamado do pensamento messiânico e os flertes com a religião. $\mathrm{O}$ autor de $A$ Ontologia do ser social permaneceu insensível a toda especulação sobre o além, ele foi até o fim um pensador da Diesseitigkeit, da pura existência terrestre, sem qualquer concessão à transcendência, seja ao messianismo, seja à "messianidade sem messianismo".

\section{Notas}

1 Publicado em tradução para o português de G. Vianna Konder também em 1967 pela Editora Paz e Terra, Rio de Janeiro. 
2 Wie ist kritische Ontologie überhaupt möglich? (Como a ontologia crítica, apesar de tudo, é possível?) era intitulado o estudo publicado por Hartmann em 1924 no volume de homenagem a Paul Natorp.

3 Cf. nosso comentário in. TERTULIAN, Nicolas. Gedanken zur Ontologie des gesellschaftlichen Seins, angefangen bei den Prolegomena no volume Objektive Möglichkeit Beiträge zu Georg Lukacs' "Zur Ontologie des gesellschaftlichen Seins”, Rüdiger Danneman. Werner Jung Hrsg., Opladen, Westdeutcher Verlag (1995, p. 148-150).

4 Em seu prefácio de 1967, Lukács desculpa-se pela falta do conceito de trabalho, com seus múltiplos corolários, em seu livro História e consciência de classe, que se tornou o catequismo do "marxismo ocidental".

5 Trata-se, na verdade, da primeira seção do livro, do capítulo consagrado ao belo natural: "Probleme der Naturschönheit".

6 Encontramos um testemunho interessante sobre a viva reação de Bloch, quando ele soube que Lukács se dedicou, na fase final de seu trajeto intelectual, à elaboração de uma ontologia. Recebendo em Tübingen o filho de Lukács e sua esposa em 24 de setembro de 1971, alguns meses após o falecimento de seu antigo amigo, Bloch recebeu as informaçóes sobre opus postumum de Lukács com as reflexóes muito contraditórias, marcadas pela surpresa de saber que o último Lukács edificou um projeto ontológico: se ele se mostrava longe de repudiar uma tal iniciativa, relembrando a ele mesmo que havia publicado um escrito intitulado Zur Ontologie des Noch-Nicht-Seins (Para uma ontologia do não ser, 1961), ele não escondia seu desapontamento diante do interesse de Lukács pela ontologia de Nicolai Hartmann ("epígono de Aristóteles", ou pior, "epígono de Boutroux", segundo o entusiasta Bloch), e, sobretudo, ele fazia ressurgir suas antigas recriminações contra as propensôes "neoclássicas" de seu amigo, identificando a ontologia por um atalho rápido a uma "idolatria da ordem" ou a uma "topologia da ordem", se não a um pensamento dos invariantes do ser, dificilmente conciliáveis com o historicismo profundo do marxismo. Em tudo e por tudo, podemos, no entanto, dizer que Bloch foi sensível à iniciativa ontológica de Lukács e que, no ano seguinte, 1972, ele vai elaborar sua própria síntese do pensamento das categorias, Experimentum Mundi (tradução francesa: Editora Payot) (BLOCH, 1984).

7 Georg Lukacs Die Eigenart des Ästhetischen, II. Halbband, p. 607, 1963, Neuwied, Luchterhand. 
8 Tradução dos Títulos: "Madame Jenny Treibel", "A Negra do Narciso"; Sob os Olhos do Ocidente". (Nota da tradutora).

9 "Resposta responsável a uma questão frívola".

10 "Sobre a fragilidade do belo e o caráter aventureiro do artista."

11 O texto figura na coleção de Oskar Becker intitulada Dasein und Dawesen: gesammelte philosophische Aufsätze.

$12 \mathrm{O}$ confronto Heidegger-Lukács esboçado aqui será desenvolvido no texto intitulado Ontologie heidéggerienne et ontologie lukacsienne, do qual uma parte foi publicada na forma de um texto autônomo (TERTULIAN, 2008).

13 A tradução francesa não contém a história da conversação entre Fischer e Bauer. Há uma nota do editor indicando que os cortes foram feitos pelo autor.

14 O acaso e a necessidade.

\section{Referências}

ADORNO, Theodor W. Ad Lukacs. Gesammelte Schriften, v. 20, n. 1, p. 251-256, Suhrkamp 1986.

ADORNO, Theodor W. Ontologie und dialektik. Frankfurt am Main, 2002.

ANDERS, Günter. Die schein-konkretheit von heideggers philosophie.

Verlag: C. H. Beck, 2001. p. 82-88.

BECKER, Oskar. "Sur la fragilité du beau et le caractère aventurier de l'artiste" dans le volume Dasein und Dawesen, gesammelte philosophische Aufsätze, 1963, Pfullingen, Neske.

BLOCH, Ernst. Gelebtes Denken. In: BLOCH, Ernst; LUKACS,

Georg. Dokumente Zum 100. Budapest, 1984. p. 296-323.

FEHER, Heller Markus. Vajda Aufzeichnungen für Genossen Lukacs zur Ontologie. In: LUKACS, Georg. Jenseits der Polemiken. Frankfurt am Main: Rüdiger Dannemann,1986. p. 209-254.

FISCHER, Ernst. Erinnerungen und Reflexionen. Reinbeck bei Hamburg: Rowohlt Verlag, 1969. p. 340-349.

HABERMAS, Jürgen. Theorie des kommunikativen Handelns. Zweite Auflage. Suhrkamp, 1982. p. 487-488. 
HARTMAN, Nicolai Hartmann. Zur Grundlegung der Ontologie. Vierte Auflage, Berlin: Walter Gruyter \& Comp., 1965. p. 41-42.

HARTMANN, Nicolai. Möglichkeit und Wirklichkeit. In: LUKACS, Georg. Zur Ontologie des gesellschaftlichen Seins. Frankfurt am Main:

Rüdiger Dannemann; Werner Jung Hrsg, 1995. p. 38-39.

HARTMANN, Nicolai. Philosophie der Natur. Berlin: Walter de Gruyter \& Co., 1950. 34. Kapitel. p. 401-410.

HARTMANN, Nicolai. Wie ist kritische Ontologie überhaupt möglich. Walter de Gruyter \& Comp., v. III, p. 268-313, 1958.

HEIDEGGER, Martin. Sein und Zeit. 5. Auflage. Max Niemeyer Verlag: Halle a.d. S., 1941. p. 143-144.

LÖWITH, Karl. Zu Heideggers Seinsfrage: Die Natur des Menschen und die Welt der Natur. Stuttgart, Metzler, 1969. p. 276-289.

LUKÁCS, Georg. Der junge Hegel und die Probleme der kapitalistischen Gesellschaft. Berlin, Aufbau-Verlag, 1954. p. 342-343.

LUKÁCS, Georg. Die Eigenart des Ästhetischen. Zweiter Halbband, Luchterhand, v. 12, 1963, p. 576-606.

LUKÁCS, Georg. Geschichte und Klassenbewusstsein. Band 2.

Luchterhand, 1967. p. 11-41.

LUKÁCS, Georg. Prolegomena zur Ontologie des gesellschaftlichen. Luchterhand, 1984. p. 149.

LUKÁCS, Georg. Prolegomena zur Ontologie. Luchterhand, 1984. p. 78-79. LUKÁCS, Georg. Zur Ontologie des gesellschaftlichen Seins. Frankfurt am Main: Rüdiger Dannemann; Werner Jung Hrsg, 1995. p. 148-150.

LUKÁCS, Georg. Zur Ontologie des gesellschaftlichen Seins. Luchterhand, 1986. p. 64-65.

POMIAN, Krzysztof. La Querelle du déterminisme. Le Débat: Gallimard, 1990.

TERTULIAN, Nicolas. L'ontologie chez Heidegger et Lukacs:

Phénoménologie et dialectique. Les Temps Modernes, n. 650, p. 270-289, juillet/octobre 2008 . 


\section{About the ontological-genetic method in Philosophy}

\section{Abstract}

The starting point of the author is the observation that Lukács' statute in the contemporary philosophical scenery is far from being elucidated. A ponderous silence surrounds, after many decades, his two works of synthesis: The Aesthetics and The Ontology of the social being. On the other hand, now it means to show that Lukács has been the first to undertake a genealogy of the multiple activities of the conscience and their objectifications (economy, rights, politics and its institutions, art or philosophy) from the dialectical tension between subjectivity and objectivity. That is to say, there is in the last thought of the Hungarian philosopher an "ontological-genetic" method, since it is attached to show the progressive stratification of the subject (for example: utilitarian activity, hedonistic activity and aesthetic activity), indicating the transitions and mediations, until the circumscription of each specificity in function of the role that it fills in social life phenomenology.

Keywords: Ontology, G. Lukács, Method.

\section{De la méthode ontologique- génétique en Philosophie}

\section{Résumé}

Le point de départ de l'auteur c'est la constatation que le statut de Lukacs dans le paysage philosophique contemporain est loin d'être élucidé. Un silence pesant entoure depuis plusieurs décennies ses deux ouvrages de synthèse: l'Esthétique et l'Ontologie de l'être social. En revanche, il s'agit maintenant de montrer que Lukács a été le premier à entreprendre une généalogie des multiples activités de la conscience et de leurs objectivations (l'économie, le droit, la politique et ses institutions, l'art ou la philosophie) à partir de la tension dialectique entre subjectivité et objectivité. C'est-à-dire, il y a dans la dernière pensée du philosophe hongrois une méthode " ontologique-génétique ", puisque elle s'attache à montrer la stratification progressive des activités du sujet (par exemple : activité utilitaire, activité hédoniste et activité esthétique), en indiquant les transitions et les médiations, jusqu’à circonscrire la spécificité de chacune en fonction du rôle qu'elle remplit dans la phénoménologie de la vie sociale.

Mots-clés: Ontologie. G. Lukács. Méthode. 
Nicolas Tertulian

E-mail: ntertulian@hotmail.com

Fone: +330147998853

Traduçáo de Gloria Goulart da Silva Campos

E-mail:glo.goulart@gmail.com

Recebido em: 30/6/2009

Aprovado em: 15/9/2009 